\title{
Microbiota of frozen Vietnamese catfish (Pangasius hypophthalmus) marketed in Belgium
}

\author{
Anh Ngoc Tong Thi ${ }^{1,2}$, Simbarashe Samapundo ${ }^{1}$, Frank Devlieghere ${ }^{1 *}$ and Marc Heyndrickx ${ }^{3,4}$
}

\begin{abstract}
Background: Vietnamese catfish (Pangasius hypophthalmus) is highly appreciated in many European countries, the U.S., Canada, Japan etc. This paper presents an overview of the microbiota of frozen Vietnamese catfish products marketed in Belgium. Samples of Pangasius steaks, portions and fillets from six brands were collected from supermarkets located in Ghent, Belgium.
\end{abstract}

Results: The total psychrotrophic and mesophilic aerobic counts of the samples evaluated from each brand did not differ significantly $(p>0.05)$ and ranged from 3.8-5.2 log CFU/g and 3.8-4.8 log CFU/g, respectively. Lactic acid bacteria counts varied from 2.2 to $4.1 \mathrm{log}$ CFU/g while the counts of presumptive Enterobacteriaceae ranged from 1.6 to $3.8 \mathrm{log}$ CFU/g. A total of 132 isolates were collected from the plates used to enumerate the microbial parameters mentioned above. Fourteen different genera and 18 different species were identified by means of 165 rRNA gene sequencing. The most prevalent genera of Lactococcus (31.2 \%), Staphylococcus (11.7 \%), Serratia (10.4\%), Acinetobacter (9.1\%), Enterococcus (7.8 \%) and Pseudomonas spp. (6.5\%) were identified by means of $16 \mathrm{~S}$ rRNA gene sequencing.

Conclusion: The results obtained provide an overview of the dominant microbiota on frozen Pangasius which is useful for the development of appropriate preservation techniques for thawed Pangasius products.

Keywords: Microbiota, Catfish, Pangasius, $16 \mathrm{~S}$ rRNA gene sequence

\section{Background}

Vietnamese catfish (Pangasius hypophthalmus) products, both farmed and freshwater, are appreciated in many European countries, the U.S., Canada, Japan etc. Pangasius has become an affordable 'white fish' substitute for cod and other white fleshed fish species in the West (Phan et al. 2009). Although high quantities of Vietnamese Pangasius products are exported to Western countries in frozen form (e.g. 158,000 tons in 2011) (VASEP 2014), fresh Pangasius is preferred. Hence, the trading of thawed products as 'fresh' fish is common in Western countries. However, once thawed the fish fillets deteriorate primarily through microbiological spoilage (ICMSF 2005).

The initial microbiological flora on freshly harvested, properly handled pond reared fish products typically

\footnotetext{
* Correspondence: frank.devlieghere@ugent.be

'Department of Food Safety and Food Quality, Laboratory of Food

Microbiology and Food Preservation, Food2Know, Ghent University, Coupure

Links 653, Ghent 9000, Belgium

Full list of author information is available at the end of the article
}

consists of a diverse mixture of Acinetobacter, Aeromonas, Citrobacter, Enterobacter, Escherichia, Flavobacterium, Micrococcus, Moraxella, Pseudomonas, Staphylococcus, Streptococcus and Vibrio spp. (ICMSF 2005). Obligate anaerobic lactic acid bacteria such as Carnobacterium, Lactobacillus, Enterococcus and Vagococcus are also commonly recovered from the guts of freshwater fish (Austin 2002; ICMSF 2005). More recently, isolates collected from the intestines and gills of Pangasius fish were identified by API strips as Enterobacteriaceae (49.1\% of the isolates), pseudomonads $(35.2 \%)$ and Vibrionaceae $(15.7 \%)$ (Sarter et al. 2007). Spoilage-related microbiota on Pangasius products has been well documented (Noseda et al. 2012; Tong Thi et al. 2013). The dominant microbiota on thawed Pangasius fillets stored in air and vacuum at the end of the shelf life (7 and 10 days, respectively) generally consists of Serratia and Pseudomonas spp. while lactic acid bacteria (e.g. Carnobacterium maltaromaticum and Carnobacterium divergens) and Brochothrix thermosphacta have been reported to be dominant on Pangasius products which are 
packaged under modified atmospheres (Noseda et al. 2012). Serratia and Pseudomonas spp. have also been isolated from imported frozen Vietnamese Pangasius products retailed in Denmark (Noor Uddin et al. 2013). Tong Thi et al. (2013) reported the high prevalence of Aeromonas, Acinetobacter, Lactococcus and Enterococcus spp. on fresh Pangasius fillets during processing at two companies in Vietnam. It was also determined in the same study that the microbial diversity on the products depended on the location, source of water, suppliers (fish farms) and production capacity (Tong Thi et al. 2013). The microbiota on frozen products could influence the shelf life of thawed products. Therefore, identification of the spoilage microorganisms on frozen Pangasius products will provide an overview of the spoilage microbiota on thawed products which would allow processors to select appropriate preservation methods for thawed products.

The major objective of this study was to determine the microbiota of frozen Vietnamese Pangasius products sold in Belgium by means of a combination of culturedependent techniques and 16S rRNA gene sequencing.

\section{Methods}

Six different brands of frozen fish products sold as Vietnamese Pangasius in various retail outlets in Ghent (Belgium) were available at the time of sampling and were evaluated in this study. Four brands were in the form of fillets ( $c a$. 200-220 g/fillet), one brand was in the form of steaks (ca. 70-100 g/steak) and another in the form of portions ( $c a .70-80 \mathrm{~g} /$ piece). Three packages of each brand were purchased at the same time and kept at $-20{ }^{\circ} \mathrm{C}$ until the microbiological and chemical analyses were performed. As sub-lethal injury of bacterial cells may occur during frozen storage, the samples were initially thawed over a $24 \mathrm{~h}$ period in a refrigerator at $4.0 \pm$ $0.7^{\circ} \mathrm{C}$ in order to enhance the recovery of the contaminating bacteria before the analyses were performed.

\section{Physico-chemical characteristics: drip loss, water content, water activity, $\mathrm{pH}$ and salt content}

The drip (thawing) loss, water content, water activity $\left(a_{\mathrm{w}}\right)$, $\mathrm{pH}$ and salt content of all the Pangasius products were determined as follows. The drip loss was determined as the difference (\%) between the weight of the packaged Pangasius products after thawing with and without the exudates. The weight of the packages was determined after thawing before the exudates were removed by decanting after which the weight of the package was measured again. Thereafter a 150-200 g composite sample from each package was homogenised for $1 \mathrm{~min}$ in a commercial blender (Braun $600 \mathrm{~W}$, Spain). The $a_{\mathrm{w}}$ and $\mathrm{pH}$ of the homogenates were measured in duplicate by means of $a_{\mathrm{w}}$-kryometer (NAGY, Gaeufelden, Germany) and a SevenEasy pH meter (Mettler Toledo
GmbH, Schwerzenbach, Swizerland), respectively. The water content of each sample was determined in duplicate gravimetrically by drying a $5 \mathrm{~g}$ aliquot of homogenate in aluminium dishes containing sea sand to avoid spattering for $12 \mathrm{~h}$ at $105{ }^{\circ} \mathrm{C}$. The salt was extracted by boiling a $5 \mathrm{~g}$ homogenate in distilled water for $10 \mathrm{~min}$. The chloride content in the extract was determined by titration with silver nitrate (Merck, Darmstadt, Germany) using a $5 \%(w / v)$ chromate indicator (Merck, Darmstadt, Germany) according to the Mohr method (ISO 9297:1989).

\section{Microbiological analyses}

The fish samples for microbiological analyses were prepared separately from the fish samples for physicochemical analyses. A 150-200 g composite sample from each package was prepared for microbial analysis. A $25 \mathrm{~g}$ sample was aseptically transferred to sterile stomacher bags by means of sterile scalpels and tweezers. Primary decimal dilutions were prepared by adding $225 \mathrm{ml}$ of sterile physiological peptone saline (PPS, $0.85 \mathrm{~g} \mathrm{NaCl}$ and $1 \mathrm{~g}$ neutralized bacteriological peptone (Oxoid, Basingstoke, U.K.) per L) to each of the $25 \mathrm{~g}$ samples. The mixtures were then homogenized in a stomacher for $1 \mathrm{~min}$. Further decimal dilutions were prepared in PPS. The total psychrotrophic and mesophilic aerobic counts were determined by pour plating the decimal dilutions on Plate Count Agar (PCA, Oxoid, Basingstoke, U.K.) followed by incubation for $72 \pm 4 \mathrm{~h}$ at $22{ }^{\circ} \mathrm{C}$ and $30{ }^{\circ} \mathrm{C}$, respectively. The counts of presumptive Enterobacteriaceae were determined by pour plating (with an additional over layer) the decimal dilutions on Violet Red Bile Glucose agar (VRBGA, Oxoid, Basingstoke, U.K.). The VRBGA plates were incubated for $24 \mathrm{~h}$ at $37{ }^{\circ} \mathrm{C}$ after which all colonies were counted. Psychrotrophic lactic acid bacteria (LAB) were determined by pour plating (with an additional over layer) the decimal dilutions on de Man Rogosa Sharpe agar (MRS, Oxoid, Basingstoke, U.K) followed by incubation for $72 \pm 4 \mathrm{~h}$ at $22^{\circ} \mathrm{C}$.

\section{Isolation and identification of dominant microbiota Sample preparation}

From the three samples evaluated of each brand, 20-30 isolates were selected for identification taking into account as many different morphologies (e.g. color, size, and shape) as possible. These originated from the PCA, VRBGA, and MRS plates used for enumeration. A total of 132 isolates were purified by successive $4 \times 4$ streak plating (and microscopic analysis). The DNA was extracted from these isolates as described below.

\section{DNA-extraction}

DNA extraction was performed according to the protocol of Flamm et al. (1984) with minor modifications. In brief, 
lysostaphine (0.5 $\mathrm{mg} / \mathrm{ml}$; Sigma) and mutanolysinelysozyme solution $(1 \mathrm{U} / \mathrm{ml}$ mutanolysine, Sigma; $2.5 \mathrm{mg} /$ $\mathrm{ml}$ lysozyme, Roche) dissolved in HPLC water and TEbuffer [0.05 M Tris, (Invitrogen); 0.02 M EDTA (Merck), $\mathrm{pH}$ 8], were added to a pellet of each isolate grown on Tryptone Soya Agar (Oxoid, Basingstoke, U.K.) at $30{ }^{\circ} \mathrm{C}$ for $24 \mathrm{~h}$. The quality and quantity of DNA templates were tested beforehand by means of a spectrophotometer (Nanodrop, Isogen).

\section{rep-PCR}

All isolates were grouped into clusters on the basis of the similarity of their fingerprints obtained with (GTG) $)_{5}$ PCR, which is a rep-PCR technique. The microbial DNA was used as a template in the PCR-reaction. Reactions were carried out in $25 \mu \mathrm{l}$ volume containing microbial DNA (50 ng/ $\mu \mathrm{l}), 1 \mathrm{x}$ RedGoldstar buffer (75 mM Tris-HCl; Eurogentec) and a final concentration of $3.4 \mathrm{mM}$ of $(\mathrm{GTG})_{5}$ primer (Eurogentec), $1.5 \mathrm{mM}$ $\mathrm{Mg}_{2} \mathrm{Cl}$ (Applied Biosystems), $1 \mathrm{U}$ RedGoldStar DNA polymerase (Eurogentec) and $0.2 \mathrm{mM}$ of each deoxynucleotide triphosphate (GE Healthcare Europe $\mathrm{GmbH}$ ). Amplification was done in a Geneamp PCR 9700 Thermocycler (Applied Biosystems) using the amplification conditions as follows: initial denaturation at $95{ }^{\circ} \mathrm{C}$ for $7 \mathrm{~min}, 30$ cycles of $1 \mathrm{~min}$ at $94{ }^{\circ} \mathrm{C}, 1 \mathrm{~min}$ at $40{ }^{\circ} \mathrm{C}, 8 \mathrm{~min}$ at $65{ }^{\circ} \mathrm{C}$ and a final 16 min extension at $65^{\circ} \mathrm{C}$ (Versalovic et al. 1994). PCR products were size separated in a $1.5 \%$ Seakem LE agarose gel (Lonza) in 1xTBE buffer $(0.1 \mathrm{M}$ Tris, $0.1 \mathrm{M}$ Boric acid, $2 \mathrm{mM}$ EDTA) at $120 \mathrm{~V}$ for $4 \mathrm{~h}$. The $(\mathrm{GTG})_{5}$ profiles were visualized under UV light after staining with ethidium bromide for $30 \mathrm{~min}$. and a digital image was captured using the G:BOX camera (Syngene). The resulting fingerprints were compared using the Bionumerics version 6.5 software package (Applied Maths, SintMartens-Latem, Belgium) using the EZ load 100 bp PCR Molecular Ruler (Biorad) as normalization reference. The similarity between the fingerprints was calculated using the Pearson correlation (1\% optimization and $1 \%$ position tolerance). The fingerprints were grouped according to their similarity by use of UPGMA (unweighted pair group method with arithmetic averages algorithm).

\section{Identification of the microbial isolates by sequence analysis} A 1500 bp fragment of the 16S rRNA gene was amplified by PCR using forward 16 F27 and reserve 16R1522 primers (Brosius et al. 1978). Amplification was performed as follows: initial denaturation at $94{ }^{\circ} \mathrm{C}$ for $1 \mathrm{~min}, 25$ cycles at $94{ }^{\circ} \mathrm{C}$ for $15 \mathrm{~s}, 60^{\circ} \mathrm{C}$ for $15 \mathrm{~s}$ and $72{ }^{\circ} \mathrm{C}$ for $30 \mathrm{~s}$ followed by an elongation step at $72{ }^{\circ} \mathrm{C}$ for $8 \mathrm{~min}$. All PCR products were purified for sequencing with a High Pure PCR product purification kit (Roche) according to manufacturer's protocol and stored at $-20^{\circ} \mathrm{C}$. The quality and quantity of the purified PCR products were verified on a $1.5 \%$ agarose gel. The sequence reactions were then performed at Macrogen (Seoul, Korea), using a template of 30-50 ng PCR product DNA and $0.2 \mu \mathrm{M}$ of primer 16 F27 (16S forward primer). The partial 16S rDNA sequences (around $900 \mathrm{bp}$ ) were compared with validly published prokaryotic names in the EzTaxon server (http://www.eztaxon.org/; (Chun et al. 2007) to determine the closest phylogenetic relatives of the strains and calculate levels of $16 \mathrm{~S}$ rDNA gene sequence similarity. A minimum of $98.5 \%$ of similarity (unless otherwise indicated) with a EZTaxon entry was used to identify the isolates to the genus level and to the tentative species level. All isolates were additionally characterized by Gram staining, oxidase and catalase test.

\section{Statistical analysis}

Results of the physico-chemical characteristics and the microbiological analysis $(\log \mathrm{CFU} / \mathrm{g})$ were reported as mean value \pm standard deviation of triplicates per product (brand). Differences in the mean counts (log $\mathrm{CFU} / \mathrm{g}$ ) of the sampled products were statistically assessed using one way Analysis of Variance (ANOVA) in SPSS version 20 (IBM Inc., Chicago, Ill., USA) when a Shapiro-Wilk test indicated that the means were normally distributed. If a Levene test confirmed heteroscedasticity, a Tamhane's T2 test was used. A nonparametric Kruskal-Wallis H-type test was performed in case the data showed non-normality. Thereafter, comparison of the paired means was done using the Mann-Whitney $U$ test $(\alpha=0.05)$.

\section{Results}

\section{Physico-chemical characteristics of frozen Pangasius} marketed in Belgium

The results of physico-chemical characteristics performed on the samples are shown in Table 1 . The mean water content of the thawed Pangasius fillets ranged from 79.3 to $87.7 \%$. Fillets from brand 3 had significantly higher water content than the fillets from the other brands. The Pangasius steaks evaluated in this study had significantly lower water content $(74.0 \%)$ than the fillets and portions $(p<0.05)$. The mean drip (thaw) losses of the fillets ranged from 7.5 to $16.8 \%$. The drip losses of fillets from brand 4 (mean $=7.5 \%)$ were significantly the lowest $(p<0.05)$ of the four brands of filleted Pangasius products evaluated. The portions had the smallest drip losses $(p<0.05)$ of any of the products evaluated; these being on average $c a .3$ and 6 times lower than the fillets of brand 4 and 1, respectively. No correlation occurred between the water content and drip losses. The mean $a_{\mathrm{w}}$ values of the fillets ranged from 0.990 to 0.995 , with fillets from brand $3\left(a_{\mathrm{w}}\right.$ $0.990)$ having significantly lower $a_{\mathrm{w}}(p<0.05)$ than those of fillets from brand 1 to 2 . The steaks and portions had $a_{\mathrm{w}}$ values (both a mean of 0.994 ) which were in the same range as fillets. 
Table 1 Physico-chemical characteristics of Vietnamese Pangasius products marketed in Belgium

\begin{tabular}{lcclcc}
\hline Product type & Water content (g/100 g wet fish) & Drip loss (\%) & $a_{w}$ & pH & Salt content (\%) \\
\hline Fillets (brand 1) & $79.3 \pm 1.2^{\mathrm{a}^{*}}$ & $16.8 \pm 0.2^{\mathrm{e}^{*}}$ & $0.9950 \pm 0.0001^{\mathrm{a}^{*}}$ & $6.5 \pm 0.0^{\mathrm{a}^{*}}$ & $0.12 \pm 0.0^{\mathrm{a}^{*}}$ \\
Fillets (brand 2) & $80.5 \pm 1.5^{\mathrm{a}}$ & $10.5 \pm 1.7^{\mathrm{d}}$ & $0.9947 \pm 0.0002^{\mathrm{a}}$ & $6.7 \pm 0.3^{\mathrm{a}}$ & $0.28 \pm 0.2^{\mathrm{abcd}}$ \\
Fillets (brand 3) & $87.7 \pm 0.9^{\mathrm{c}}$ & $11.9 \pm 3.9^{\mathrm{d}}$ & $0.9896 \pm 0.0007^{\mathrm{c}}$ & $8.2 \pm 0.2^{\mathrm{c}}$ & $0.93 \pm 0.2^{\mathrm{b}}$ \\
Fillets (brand 4) & $80.0 \pm 0.3^{\mathrm{a}}$ & $7.5 \pm 0.1^{\mathrm{c}}$ & $0.9947 \pm 0.0003^{\mathrm{abc}}$ & $6.5 \pm 0.1^{\mathrm{a}}$ & $0.23 \pm 0.1^{\mathrm{c}}$ \\
Steaks (brand 5) & $74.0 \pm 2.1^{\mathrm{b}}$ & $12.6 \pm 1.8^{\mathrm{bd}}$ & $0.9939 \pm 0.0008^{\mathrm{b}}$ & $6.2 \pm 0.1^{\mathrm{b}}$ & $0.49 \pm 0.1^{\mathrm{d}}$ \\
Portions (brand 6) & $80.0 \pm 1.4^{\mathrm{a}}$ & $2.6 \pm 1.4^{\mathrm{a}}$ & $0.9944 \pm 0.0002^{\mathrm{ab}}$ & $6.5 \pm 0.1^{\mathrm{a}}$ & $0.22 \pm 0.1^{\mathrm{ac}}$ \\
\hline
\end{tabular}

"Data are expressed as mean value \pm standard deviation of three replicates. Means with a different superscript letter in the same column indicate where statistically $(p \leq 0.05)$ differences occurred between products that were evaluated in this study

The mean $\mathrm{pH}$ values of the fillets ranged from 6.5 to 8.2. The $\mathrm{pH}$ of the Pangasius fillets from brand 3 (mean $=8.2)$ were significantly higher $(p<0.05)$ than those of the fillets from the other three brands evaluated. The mean $\mathrm{pH}$ values of the portions did not differ significantly $(p>0.05)$ from that of fillets from brands 1,2 and 4, whilst the Pangasius steaks (mean $\mathrm{pH}$ value $=6.2)$ had significantly lower $\mathrm{pH}$ values $(p<0.05)$ than those of the fillets and portions. The salt content (based on the chloride content) of the fillets ranged from 0.12 to $0.93 \%$. As for the $\mathrm{pH}$, the $\mathrm{NaCl}$ content of the Pangasius fillets from brand 3 (mean $=0.93 \%$ ) were significantly higher $(p<0.05)$ than those of the fillets from the other three brands evaluated. The portions had a similar $\mathrm{NaCl}$ content to fillets of brands 1, 2 and 4 whilst the steaks had a mean $\mathrm{NaCl}$ content $(0.49 \%)$ which was significantly higher $(p<0.05)$ than those of the portions and fillets of brands 1 and 4 , but significantly smaller $(p<0.05)$ than that of fillets from brand 3.

\section{Microbiota of frozen Pangasius fish}

The microbial quality of frozen Pangasius products marketed in Belgium is shown in Table 2. The total psychrotrophic aerobic counts (TPC) ranged from 3.8 to $5.2 \mathrm{log}$ CFU/g, whilst the total mesophilic aerobic counts (TMC) ranged from 3.8 to $4.8 \mathrm{CFU} / \mathrm{g}$. The TPC and TMC for each brand of fish did not differ significantly from each other $(p>0.05)$. With regard to the fillets, it can be seen that the TPC and TMC on fillets from brand 2 were both significantly lower $(p<0.05)$ than those on fillets from the other three brands. The counts of lactic acid bacteria (LAB) varied greatly between products, with significantly lower $(p<0.05)$ LAB occurring on the fillets from brand 2 than those found on the fillets from the other three brands. However, LAB counts from brand 2 did not differ significantly $(p>0.05)$ from these counts on the steaks and portions sampled. The counts of presumptive Enterobacteriaceae were highest on the fillets from brand 1 ( $3.8 \pm 0.2 \log \mathrm{CFU} / \mathrm{g})$ while the lowest counts were found on the portions from brand 6 (1.6 \pm $0.6 \log \mathrm{CFU} / \mathrm{g})$.

\section{Identification of the isolates collected from different products}

A total of 132 isolates were collected from the plates used to enumerate the aerobic counts, presumptive Enterobacteriaceae and lactic acid bacteria on the frozen Pangasius products evaluated in this study. These isolates were clustered based on their rep-PCR fingerprints. Each cluster consisted of at least four isolates with a similarity level of at least $65 \%$. From this cluster analysis, two representative isolates of each cluster were selected for further analysis by $16 \mathrm{~S}$ rRNA gene sequencing and thereafter the tentative identification was extrapolated for the entire group of isolates in each cluster.

The identification of 76 selected isolates (of which 33 were Gram negative and 43 were Gram positive) included 14 different genera and 18 different species

Table 2 Microbiota of Vietnamese Pangasius products marketed in Belgium

\begin{tabular}{|c|c|c|c|c|}
\hline Product type & $\begin{array}{l}\text { Total psychrotrophic aerobic } \\
\text { counts (TPC) }\end{array}$ & $\begin{array}{l}\text { Total mesophilic aerobic } \\
\text { counts (TMC) }\end{array}$ & $\begin{array}{l}\text { Psychrotrophic lactic } \\
\text { acid bacteria }\end{array}$ & Presumptive Enterobacteriaceae \\
\hline Fillets (brand 1) & $4.7 \pm 0.3^{b d^{*}}$ & $4.8 \pm 0.4^{\mathrm{a}}$ & $4.0 \pm 0.7^{a}$ & $3.8 \pm 0.2^{a}$ \\
\hline Fillets (brand 2) & $3.8 \pm 0.1^{\mathrm{a}}$ & $3.8 \pm 0.0^{b}$ & $2.2 \pm 0.5^{b c}$ & $2.9 \pm 0.0^{b}$ \\
\hline Fillets (brand 3) & $5.2 \pm 0.2^{b}$ & $4.5 \pm 0.3^{\mathrm{ac}}$ & $4.1 \pm 0.1^{a}$ & $3.0 \pm 0.4^{\mathrm{bd}}$ \\
\hline Fillets (brand 4) & $5.1 \pm 0.4^{\mathrm{bd}}$ & $4.6 \pm 0.2^{\mathrm{a}}$ & $4.0 \pm 0.1^{\mathrm{a}}$ & $2.9 \pm 0.2^{b}$ \\
\hline Steaks (brand 5) & $4.6 \pm 0.2^{\mathrm{cd}}$ & $4.8 \pm 0.1^{\mathrm{a}}$ & $2.7 \pm 0.1^{c}$ & $2.5 \pm 0.2^{d}$ \\
\hline Portions (brand 6) & $4.4 \pm 0.1^{c}$ & $4.3 \pm 0.1^{c}$ & $2.3 \pm 0.1^{b}$ & $1.6 \pm 0.6^{c}$ \\
\hline
\end{tabular}

*Data are expressed as mean value \pm standard deviation (log CFU/g) of three replicates. Means with a different superscript letter in the same column indicate where statistically $(p \leq 0.05)$ differences occurred between products that were evaluated in this study 
(Table 3 and Additional file 1). On the basis of the total number of isolates identified, Acinetobacter, Serratia, Staphylococcus and Lactococcus spp. were highly frequent, representing $10.5,7.9,11.8$, and $31.6 \%$ of the isolates, respectively. Lactococcus spp. were isolated from five of the six brands evaluated, the only exception was fillets from brand 3. Enterococcus, Stenotrophomonas, Chryseobacterium and Empedobacter spp. were found only on fillets from brand 3. In addition, Serratia spp. were identified on the portions and steaks while Enterobacter and Morganella spp. were identified only on fillets from brand 1 to 4, respectively. Staphylococcus spp. was identified on the portions and fillets (from brands 1 to 2). The other microbiota identified on Pangasius sampled included Klebsiella (brand 1 and 5), Pseudomonas (brand 1 and 4), Arthrobacter (brand 2), and Macrococcus spp. (brand 1).

Table 3 Genera and species isolated from different Pangasius products sold in Belgium

\begin{tabular}{|c|c|c|c|c|c|c|c|c|}
\hline Isolate $^{a}$ & $\begin{array}{l}\text { Fillets } \\
\text { (brand 1) }\end{array}$ & $\begin{array}{l}\text { Fillets } \\
\text { (brand 2) }\end{array}$ & $\begin{array}{l}\text { Fillets } \\
\text { (brand 3) }\end{array}$ & $\begin{array}{l}\text { Fillets } \\
\text { (brand 4) }\end{array}$ & $\begin{array}{l}\text { Steaks } \\
\text { (brand 5) }\end{array}$ & $\begin{array}{l}\text { Portions } \\
\text { (brand 6) }\end{array}$ & $\begin{array}{l}\text { Total } \\
\text { isolates }\end{array}$ & Prevalence (\%) \\
\hline Acinetobacter spp. & $1^{\mathrm{b}}$ & & 3 & & 4 & & 8 & 10.5 \\
\hline Acinetobacter johnsonii & & & & & 2 & & & \\
\hline Acinetobacter beijerinckii & 1 & & 3 & & & & & \\
\hline Acinetobacter haemolyticus & & & & & 2 & & & \\
\hline Pseudomonas spp. & 2 & & & 3 & & & 5 & 6.6 \\
\hline Pseudomonas mosselii & & & & 3 & & & & \\
\hline Pseudomonas beteli & 2 & & & & & & & \\
\hline Stenotrophomonas spp. & & & 1 & & & & 1 & 1.3 \\
\hline Stenotrophomonas maltophilia & & & 1 & & & & & \\
\hline Serratia spp. & & & & & 1 & 5 & 6 & 7.9 \\
\hline Serratia nematodiphila & & & & & 1 & 5 & & \\
\hline Enterobacter spp. & 4 & & & & & & 4 & 5.3 \\
\hline Enterobacter hormaechei & 4 & & & & & & & \\
\hline Klebsiella spp. & 1 & & & & 2 & & 3 & 3.9 \\
\hline Klebsiella pneumoniae & 1 & & & & 2 & & & \\
\hline Morganella spp. & & & & 2 & & & 2 & 2.6 \\
\hline Morganella morganii & & & & 2 & & & & \\
\hline Chryseobacterium spp. & & & 2 & & & & 2 & 2.6 \\
\hline Chryseobacterium indologenes & & & 2 & & & & & \\
\hline Arthrobacter spp. & & 2 & & & & & 2 & 2.6 \\
\hline Arthrobacter protophormiae & & 2 & & & & & & \\
\hline Lactococcus spp. & 2 & 3 & & 8 & 7 & 4 & 24 & 31.6 \\
\hline Lactococcus garvieae & & 3 & & 8 & 7 & 4 & & \\
\hline Lactococcus lactis & 2 & & & & & & & \\
\hline Enterococcus spp. & & & 6 & & & & 6 & 7.9 \\
\hline Enterococcus casseliflavus & & & 6 & & & & & \\
\hline Macrococcus spp. & 2 & & & & & & 2 & 2.6 \\
\hline Macrococcus caseolyticus & 2 & & & & & & & \\
\hline Staphylococcus spp. & 2 & 1 & & & & 6 & 9 & 11.8 \\
\hline Staphylococcus sciuri & 2 & 1 & & & & 6 & & \\
\hline Empedobacter spp. & & & 2 & & & & 2 & 2.6 \\
\hline Empedobacter brevis & & & 2 & & & & & \\
\hline Total of strain abundance & 14 & 6 & 14 & 13 & 14 & 15 & 76 & 100 \\
\hline Number of species & 7 & 3 & 5 & 3 & 5 & 3 & & \\
\hline
\end{tabular}

Identification results on genus and species level; species identifications are only tentative

${ }^{\text {b}}$ The frequency of identified isolates based on rep-clustering and partial $16 \mathrm{~S}$ rRNA gene sequence analysis with cut-off value of $98.5 \%$ similarity with type strains of validly published prokaryotic names in EZTaxon database. The percentage of total number of isolates of each genus is listed in the last column 


\section{Discussion}

\section{Physico-chemical characteristics}

The results of the physico-chemical characteristics analyses of the frozen Vietnamese Pangasius products marketed in Belgium generally confirmed the findings of previous studies on Pangasius products. In agreement with our findings, Usydus et al. (2011) determined that the water content of frozen Vietnamese Pangasius products marketed in Poland was $84.7 \pm 0.3 \%$. Karl et al. (2010) reported that frozen Vietnamese Pangasius products marketed in Germany had lower values of water content which ranged from 78.1 to $83.3 \%$, value of drip losses between 12.5 and $24.6 \%$ and $\mathrm{pH}$ values between 6.3 and 7.6. Orban et al. (2008) reported that frozen Vietnamese Pangasius products marketed in Italy had values of water content which ranged from 80.1 to $85.0 \%$, and $\mathrm{pH}$ values between 7.56 and 7.96. In the same study, a high sodium content (0.222-0.594\%) was determined in the Pangasius products. This was assumed to be a result of the fish being possibly treated with water-binding additives of polyphosphate before freezing (Orban et al. 2008). The same conclusion was also derived by Karl et al. (2010) for Pangasius products marked in Germany by means of differential scanning calorimetry which showed a decreased thermal stability in the protein domains of the fish. The use of phosphate in both fish and meat can increase water retention and reduce thaw loss as a result of an increase in the $\mathrm{pH}$ and ionic strength and binding of phosphate to the protein (Thorarinsdottir et al. 2001; Kaufmann et al. 2005; Gonçalves et al. 2008). Brand 3 fillets were most likely treated with water-binding additives as they had the highest water content $(87.7 \pm 0.9 \%)$, lowest water activity (0.9896 \pm $0.0007)$, highest $\mathrm{pH}(8.2 \pm 0.2)$ and a very high salt content $(0.93 \pm 0.2 \%)$. It is necessary to investigate further the composition of additives used during processing and their impacts on the quality and safety in general and the microbiota of Pangasius products in particular.

\section{Microbiota of frozen Pangasius products marketed in Belgium}

The TPC (3.8 to $5.2 \log$ CFU/g) on the Pangasius products were not significantly different $(p>0.05)$ from the TMC (3.8 to $4.8 \log$ CFU/g). These values are below the acceptance limit for frozen Pangasius fillets established by Vietnamese Science \& Technology Ministry (TCVN 2010) and for fresh fish developed by the Laboratory of Food Microbiology and Food Preservation (Ghent University) (Uyttendaele et al. 2010). Moreover, the TMC cannot always give a realistic estimation of the microbial contamination levels in food, especially foods stored at chilling or freezing temperatures. Some previous studies have reported that the TMC are not sufficient for enumerating the microbial counts of a packaged food product stored at chilling or freezing temperature (Broekaert et al. 2011; Pothakos et al. 2012). However, either TPC or TMC can use to enumerate the total microbia counts for frozen Pangasius fillets (orginated from the tropical areas of Vietnam). This is consistent with previous results observed on frozen Pangasius originating from Vietnam that were processed for export to Belgium and other European countries (Tong Thi et al. 2013; Noseda et al. 2013; Noseda et al. 2012). The lactic acid bacteria (LAB) counts varied greatly between the products. The highest $\mathrm{LAB}$ counts, $4.1 \pm 0.1 \mathrm{log} \mathrm{CFU} / \mathrm{g}$, were observed on the fillets from brand 3 . These counts were in agreement with those obtained by Noseda et al. (2012), who found $3.9 \pm 0.1 \log \mathrm{CFU} / \mathrm{g}$ of $\mathrm{LAB}$ on thawed frozen Vietnamese Pangasius intended for a study regarding the effect of modified atmosphere packaging. However, these and our counts were generally higher than those observed on frozen Pangasius fish sampled after production in Vietnam $(1.5 \pm 0.3$ to $3.4 \pm 0.4 \log \mathrm{CFU} / \mathrm{g})$ (Tong Thi et al. 2013). It is possible that the mesophilic LAB on the frozen Pangasius fish sampled after production in Vietnam were less dominant than the psychrotrophic LAB on the Pangasius fillets evaluated in this study and by Noseda et al. (2012). Of the LAB identified in the samples, Lactococcus spp. were the most prevalent $(31.6 \%)$. These results were in agreement with the findings of our previous study on Pangasius fish during processing (Tong Thi et al. 2013). Lactococcus and Enterococcus spp. have previously been isolated from lightly preserved salmon products such as cold smoked, salted and dried salmon (Françoise 2010). Both L. lactis and L. garvieae are also associated with fresh and marine water in tropical areas (Michel et al. 2007). In addition to their association with fish farm environments, they are also sometimes isolated from human and other mammalian clinical cases (Michel et al. 2007).

Enterococcus spp. can tolerate high salts concentrations (Harwood et al. 2000), which can explain that they were only isolated from brand 3 fillets. With regard to the presumptive Enterobacteriaceae, various isolates of Enterobacter, Klebsiella, Morganella and Serratia spp. were identified. The incidence of these isolates appeared to be dependent on how the frozen Pangasius was processed as Serratia was isolated from steaks and portioned Pangasius products, whilst Enterobacter and Klebsiella were isolated from fillets (brand 1) and Morganella from fillets (brand 4). Differences between the types of Enterobacteriaceae contaminating frozen Pangasius products in Vietnam have also been found on the basis of the size of the processing plant. Frozen Pangasius fillets processed in a large plant were determined to be contaminated by Serratia spp. whereas those processed in a 
small scale plant were contaminated by Enterobacter, Klebsiella, and Morganella spp. (Tong Thi et al. 2013). Kim et al. (2003) also pointed to the importance of sanitation in the fish processing plant to prevent cross-contamination with Enterobacter, Klebsiella, and Morganella. Moreover, species belonging to the Enterobacteriaceae family are in general frequently isolated from intestines of tropical and farmed fish (ICMSF 2005; Apun et al. 1999) and Vietnamese Pangasius (Sarter et al. 2007; Tong Thi et al. 2013). Contamination of the flesh by these species is likely to occur during gutting (for Pangasius steaks) and manually filleting (for fillets and portions) (Tong Thi et al. 2013; Noseda et al. 2013; Tong Thi et al. 2014). Based on our previous studies, it is suggested that producers have to pay a lot of attention during gutting and filleting such as sanitation of knives, gloves, cutting boards, etc. in order to control the microbial quality. In other words, both gutting and filleting steps may be suggested as critical control points during processing Pangasius products. Similarly, based on our findings of Tong Thi et al. (2013) combined with the results obtained from this study, we suggest that Enterobacter, Klebsiella, Morganella and Serratia spp. may be good indicators of the microbial quality for Pangasius fish. The growth of these species can be prevented by applying low temperature (i.e. 0 to $4{ }^{\circ} \mathrm{C}$ ) and modified atmosphere packaging techniques such as vacuum or packaging in modified atmospheres (Baylis 2006). Furthermore, the counts of presumptive Enterobacteriaceae were highly variable among the products, ranging from $1.6 \pm 0.6$ to $3.8 \pm 0.2 \log \mathrm{CFU} / \mathrm{g}$. It has to be mentioned that the approach used in this study can only give an idea of the presumptive Enterobacteriaceae. Acinetobacter and Pseudomonas spp. were also identified for isolates growing not only on non-selective PCA but also on selective VRBGA plates.

The ability of Acinetobacter spp. to grow on both nonselective (PCA) and selective media (VRBGA), may have contributed to the high prevalence of Acinetobacter spp. (10.5\%) on the frozen Pangasius fish evaluated in this study. In addition, Acinetobacter and Pseudomonas spp. have been isolated from the intestines of fish (Hovda et al. 2007; Merrifield et al. 2009; Ringø et al. 2006) and therefore may potentially contaminate the fish during processing. This is supported by our previous findings where Acinetobacter and Pseudomonas spp. were detected on Pangasius samples collected at the filleting and trimming steps of processing in Vietnamese companies (Tong Thi et al. 2013). Moreover, Pseudomonas spp. have also been determined to be the dominant spoilage bacteria on thawed Pangasius stored in air at $4{ }^{\circ} \mathrm{C}$ (Noseda et al. 2012). The spoilage capacity of the isolates identified in this study should be further evaluated to provide better insights into their spoilage mechanisms.
The prevalence of Staphylococcus sciuri (11.8\%) on frozen Pangasius was relatively high. Staphylococcus sciuri has found in humans (Stepanović et al. 2005) and also in gut (Boari et al. 2008), therefore they could have been transferred to the products via human contact during handling and processing. S. sciuri has been identified in various food products of animal origins such as meat and meat products; milk and milk products and fish and fish products (Garcia et al. 2002; Papamanoli et al. 2002). S. sciuri is the most frequently reported histamine-forming bacterium in cod, escolar steaks, swordfish fillets, cold smoked rainbow trout and whole and filleted catfish (Hwang et al. 2012; Chang et al. 2008; Ramos and Lyon 2000).

Empedobacter, Macrococcus, Arthrobacter, Chryseobacterium and Stenotrophomonas spp. were less prevalent in the frozen Pangasius products evaluated in this study. Stenotrophomonas maltophilia, an important opportunistic pathogen, has been also isolated from channel catfish in China (Geng et al. 2010). Chryseobacterium indologenes has also been found on Pangasius fish sampled during processing in Vietnam (Tong Thi et al. 2013) and frozen Pangasius exported to Denmark (Noor Uddin et al. 2013). Chryseobacterium indologenes has been isolated from diseased yellow perch (Pridgeon et al. 2013) whilst Chryseobacterium spp. are known to be widely distributed in the environment and soil (Benmalek et al. 2010), and fresh water (Kim et al. 2008; Park et al. 2008).

\section{Conclusion}

A high prevalence of Pseudomonas (6.5\%), Enterococcus (7.8\%), Acinetobacter (9.1\%), Serratia (10.4\%), Staphylococcus (11.7 \%) and Lactococcus spp. (31.2 \%) was determined on thawed Vietnamese Pangasius products marketed in Belgium. These results are crucial as currently very little is known about the microbiota of thawed Pangasius products marketed in the West as 'fresh' Pangasius products. This knowledge is important with regards to the development of suitable preservation techniques such as vacuum and modified atmosphere packaging to inhibit the microorganisms contaminating thawed Pangasius fish.

\section{Additional file}

Additional file 1: Dendrograms generated after cluster analysis of the (GTG)5-PCR fingerprints of isolates from brand 1 to brand 6. (DOCX $197 \mathrm{~kb}$ )

\section{Acknowledgments}

Grants from Research Foundation Flanders (FWO/project number:

GA02012N) and Ministry of Education and Training of Viet Nam (MOET) are acknowledged. We are grateful to Pieter Siau, Ann Vanhee and Ann Dirckx for their practical guidance and assistance. 


\section{Authors' contributions}

ANTT contributed to the sampling and analysis. FD and MH contributed to the design of the study. ANTT, FD and MH contributed to the interpretation of data and drafting the manuscript. SS contributed to critical revision of the paper. All authors read and approved the final manuscript.

\section{Competing interests}

The authors declare that they have no competing interests.

\section{Author details}

${ }^{1}$ Department of Food Safety and Food Quality, Laboratory of Food Microbiology and Food Preservation, Food2Know, Ghent University, Coupure Links 653, Ghent 9000, Belgium. ²Department of Food Technology, Faculty of Agriculture and Applied Biology, Can Tho University, 3-2 Street, Can Tho City, Viet Nam. ${ }^{3}$ Institute for Agricultural and Fisheries Research (ILVO), Technology and Food Science Unit, Brusselsesteenweg 370, Melle 9090, Belgium. ${ }^{4}$ Department of Pathology, Bacteriology and Avian Diseases, Faculty of Veterinary Medicine, Ghent University, Salisburylaan 133, Merelbeke 9820, Belgium.

\section{Received: 26 July 2016 Accepted: 11 October 2016}

\section{Published online: 18 October 2016}

\section{References}

Apun K, Yusof AM, Jugang K. Distribution of bacteria in tropical freshwater fish and ponds. Int J Environ Health Res. 1999:9(4):285-92.

Austin B. The bacterial microflora of fish. Sci World J. 2002;2(3):558-72.

Baylis CL. Food Spoilage Microorganisms. In: Blackburn CW, editor. Food Science, Technology And Nutrition. New York: Woodhead Publishing; 2006. p. 624-67.

Benmalek Y, Cayol J-L, Bouanane NA, Hacene H, Fauque G, Fardeau M-L. Chryseobacterium solincola sp. nov., isolated from soil. Int I Syst Evol Microbiol. 2010;60(8):1876-80.

Boari CA, Pereira Gl, Valeriano C, Silva BC, Morais VM, Figueiredo HCP, Piccoli RH. Bacterial ecology of tilapia fresh fillets and some factors that can influence their microbial quality. Food Sci Tech (Campinas). 2008;28(4):863-7.

Broekaert K, Heyndrickx M, Herman L, Devlieghere F, Vlaemynck G. Seafood quality analysis: molecular identification of dominant microbiota after ice storage on several general growth media. Food Microbiol. 2011;28(6):1162-9.

Brosius J, Palmer ML, Kennedy PJ, Noller HF. Complete nucleotide sequence of a 165 ribosomal RNA gene from Escherichia coli. Proc Natl Acad Sci. 1978;75:4801-5.

Chang S-C, Kung H-F, Chen H-C, Lin C-S, Tsai Y-H. Determination of histamine and bacterial isolation in swordfish fillets (Xiphias gladius) implicated in a food borne poisoning. Food Control. 2008;19(1):16-21.

Chun J, Lee J-H, Jung Y, Kim M, Kim S, Kim BK, Lim Y-W. EzTaxon: a web-based tool for the identification of prokaryotes based on 165 ribosomal RNA gene sequences. Int J Syst Evol Microbiol. 2007;57(10):2259-61.

Flamm RK, Hinrichs DJ, Thomashow MF. Introduction of pAMb1 into Listeria monocytogenes by conjugation and homology between native $L$. monocytogenes plasmids. Infect Immun. 1984;44:157-61.

Françoise L. Occurrence and role of lactic acid bacteria in seafood products. Food Microbiol. 2010;27(6):698-709.

Garcia M, Rodriguez M, Bernardo A, Tornadijo M, Carballo J. Study of enterococci and micrococci isolated throughout manufacture and ripening of San Simón cheese. Food Microbiol. 2002;19(1):23-33.

Geng Y, Wang K, Chen D, Huang X, He M, Yin Z. Stenotrophomonas maltophilia, an emerging opportunist pathogen for cultured channel catfish, Ictalurus punctatus, in China. Aquaculture. 2010;308(3-4):132-5.

Gonçalves AA, Rech BT, Rodrigues P, Pucci D. Quality evaluation of frozen seafood (Genypterus brasiliensis, Prionotus punctatus, Pleoticus muelleri and Perna perna) previously treated with phosphates. Pan-Am J Aquat Sci. 2008;3(3):248-58.

Harwood VJ, Whitlock J, Withington V. Classification of antibiotic resistance patterns of indicator bacteria by discriminant analysis: use in predicting the source of fecal contamination in subtropical waters. Appl Environ Microbiol. 2000;66(9):3698-704.

Hovda MB, Lunestad BT, Fontanillas R, Rosnes JT. Molecular characterisation of the intestinal microbiota of farmed Atlantic salmon (Salmo salar L.). Aquaculture. 2007;272(1):581-8.

Hwang C-C, Lin C-M, Huang C-Y, Huang Y-L, Kang F-C, Hwang D-F, Tsai Y-H. Chemical characterisation, biogenic amines contents, and identification of fish species in cod and escolar steaks, and salted escolar roe products. Food Control. 2012;25(1):415-20.
ICMSF. Micro-organisms in Food 6: Microbiological ecology of food commodities. New York: Kluwer Academic/Plenum Publishers; 2005. p. 174-249.

Karl H, Lehmann I, Rehbein H, Schubring R. Composition and quality attributes of conventionally and organically farmed Pangasius fillets (Pangasius hypophthalmus) on the German market. Int J Food Sci Tech. 2010;45(1):56-66.

Kaufmann A, Maden K, Leisser W, Matera M, Gude T. Analysis of polyphosphates in fish and shrimps tissues by two different ion chromatography methods: Implications on false-negative and-positive findings. Food Addit Contam. 2005;22(11):1073-82.

Kim KK, Lee KC, Oh H-M, Lee J-S. Chryseobacterium aquaticum sp. nov., isolated from a water reservoir. Int J Syst Evol Microbiol. 2008;58(3):533-7.

Kim SH, An H, Wei Cl, Visessanguan W, Benjakul S, Morrissey MT, Su YC, Pitta TP. Molecular Detection of a Histamine Former, Morganella morganii, in Albacore, Mackerel, Sardine, and a Processing Plant. J Food Sci. 2003;68(2):453-7.

Merrifield DL, Burnard D, Bradley G, Davies SJ, Baker RTM. Microbial community diversity associated with the intestinal mucosa of farmed rainbow trout (Oncoryhnchus mykiss Walbaum). Aqua Res. 2009;40(9):1064-72.

Michel C, Pelletier C, Boussaha M, Douet DG, Lautraite A, Tailliez P. Diversity of lactic acid bacteria associated with fish and the fish farm environment, established by amplified rRNA gene restriction analysis. Appl Environ Microbiol. 2007;73(9):2947-55.

Noor Uddin GM, Larsen MH, Guardabassi L, Dalsgaard A. Bacterial flora and antimicrobial resistance in raw frozen cultured seafood imported to Denmark. J Food Prot. 2013;76(3):490-9.

Noseda B, Islam MT, Eriksson M, Heyndrickx M, De Reu K, Van Langenhove H, Devlieghere F. Microbiological spoilage of vacuum and modified atmosphere packaged Vietnamese Pangasius hypophthalmus fillets. Food Microbiol. 2012; 30(2):408-19.

Noseda B, Tong Thi AN, Rosseel L, Devlieghere F, Jacxsens L. Dynamics of microbiological quality and safety of Vietnamese Pangasianodon hypophthalmus during processing. Aquac Int. 2013;21(3):709-27.

Orban E, Nevigato T, Lena GD, Masci M, Casini I, Gambelli L, Caproni R. New trends in the seafood market. Sutchi catfish (Pangasius hypophthalmus) fillets from Vietnam: Nutritional quality and safety aspects. Food Chem. 2008:110(2):383-9.

Papamanoli E, Kotzekidou P, Tzanetakis N, Litopoulou-Tzanetaki E. Characterization of Micrococcaceae isolated from dry fermented sausage. Food Microbiol. 2002;19(5):441-9.

Park SC, Kim MS, Baik KS, Kim EM, Rhee MS, Seong CN. Chryseobacterium aquifrigidense sp. nov., isolated from a water-cooling system. Int J Syst Evol Microbiol. 2008;58(3):607-11.

Phan LT, Bui TM, Nguyen TT, Gooley GJ, Ingram BA, Nguyen HV, Nguyen PT, De Silva SS. Current status of farming practices of striped catfish, Pangasianodon hypophthalmus in the Mekong Delta, Vietnam. Aquaculture. 2009;296(3):227-36.

Pothakos V, Samapundo S, Devlieghere F. Total mesophilic counts underestimate in many cases the contamination levels of psychrotrophic lactic acid bacteria $(\mathrm{LAB})$ in chilled-stored food products at the end of their shelf-life. Food Microbiol. 2012;32(2):437-43.

Pridgeon J, Klesius P, Garcia J. Identification and virulence of Chryseobacterium indologenes isolated from diseased yellow perch (Perca flavescens). J Appl Microbiol. 2013;114(3):636-43.

Ramos M, Lyon WJ. Reduction of endogenous bacteria associated with catfish fillets using the Grovac process. J Food Prot. 2000;63(9):1231-9.

Ring $\varnothing$ E, Sperstad S, Myklebust R, Refstie S, Krogdahl $\AA$. Characterisation of the microbiota associated with intestine of Atlantic cod (Gadus morhua L.): The effect of fish meal, standard soybean meal and a bioprocessed soybean meal. Aquaculture. 2006;261(3):829-41.

Sarter S, Kha Nguyen HN, Hung LT, Lazard J, Montet D. Antibiotic resistance in Gram-negative bacteria isolated from farmed catfish. Food Control. 2007; 18(11):1391-6.

Stepanović S, Dakić I, Martel A, Vaneechoutte M, Morrison D, Shittu A, Ježek P, Decostere A, Devriese LA, Haesebrouck F. A comparative evaluation of phenotypic and molecular methods in the identification of members of the Staphylococcus sciuri group. Syst Appl Microbiol. 2005;28(4):353-7.

TCVN. Officially legal criteria for frozen Tra fish (Pangasius hypophthalmus) fillet established by Vietnamese Science \& Technology Ministry. Reference number: TCVN 8338: 2010. 2010.

Thorarinsdottir K, Arason S, Bogason SG, Kristbergsson K. Effects of phosphate on yield, quality, and water-holding capacity in the processing of salted cod (Gadus morhua). J Food Sci. 2001;66(6):821-6. 
Tong Thi AN, Jacxsens L, Noseda B, Samapundo S, Nguyen BL, Heyndrickx M, Devlieghere F. Evaluation of the microbiological safety and quality of Vietnamese Pangasius hypophthalmus during processing by a microbial assessment scheme in combination with a self-assessment questionnaire. Fish Sci. 2014;80(5):1117-28.

Tong Thi AN, Noseda B, Samapundo S, Nguyen BL, Broekaert K, Rasschaert G, Heyndrickx M, Devlieghere F. Microbial ecology of Vietnamese Tra fish (Pangasius hypophthalmus) fillets during processing. Int J Food Microbiol. 2013;167(2):144-52.

Usydus Z, Szlinder-Richert J, Adamczyk M, Szatkowska U. Marine and farmed fish in the Polish market: Comparison of the nutritional value. Food Chem. 2011;126(1):78-84.

Uyttendaele M, Jacxsens L, De Loy-Hendrickx A, Devlieghere F, Debevere J. Microbiological guide values and legal criteria. Ghent: Ghent University; 2010

VASEP. Viet Nam Association of Seafood Exporters and Producers; 2014 http://www.pangasius-vietnam.com/378/Daily-News-p/About-Pangasius. htm. Accessed on 15 Aug 2014

Versalovic J, Schneider M, De Bruijn FJ, Lupski JR. Genomic fingerprinting of bacteria using repetitive sequence-based polymerase chain reaction. Methods Mol Cell Biol. 1994;5(1):25-40.

\section{Submit your manuscript to a SpringerOpen ${ }^{\circ}$ journal and benefit from:}

- Convenient online submission

- Rigorous peer review

- Immediate publication on acceptance

- Open access: articles freely available online

- High visibility within the field

- Retaining the copyright to your article

Submit your next manuscript at $\gg$ springeropen.com 